\title{
بسطامى عبد الغنى رائد تعليم اللغة العربية بإندونيسيا الحديثة
}

محهد رشدى خالد

Universitas Islam Negeri Alauddin Makassar rusydi_khalid@yahoo.com

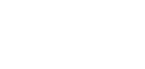

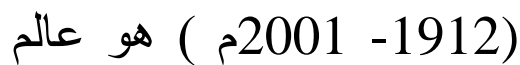

إندونيسى من سومطرة الغربية تعلم اللغة العربية و 1 إلهية

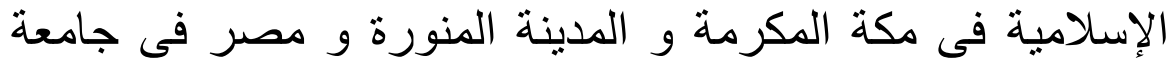

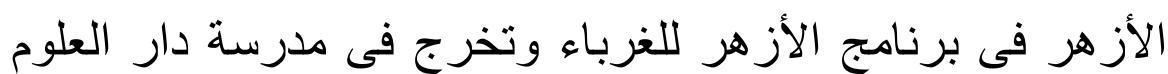
ونال إجازة التدريس. وهو رائد من رواد الاد اللغة العربية في إندونيسيا

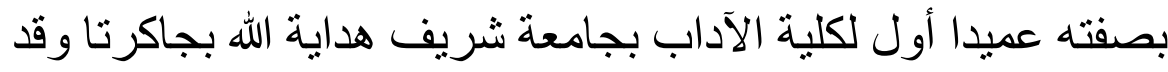
بتحديث وتجديد طرق تعليم اللغة العربية باستعمال الطريقة

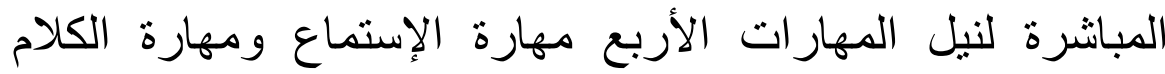

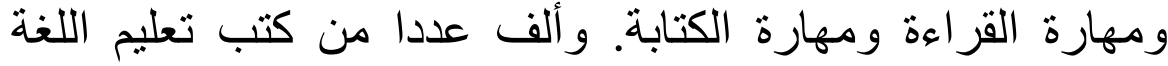

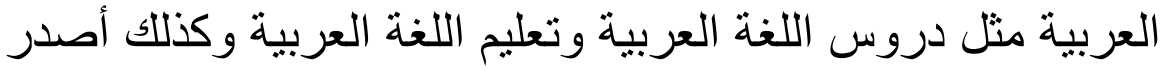

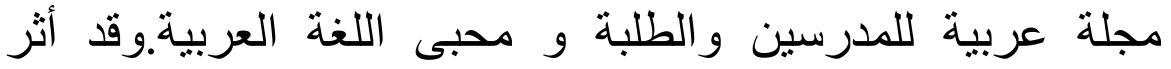

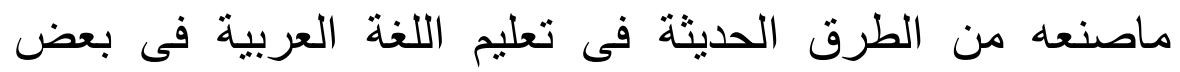

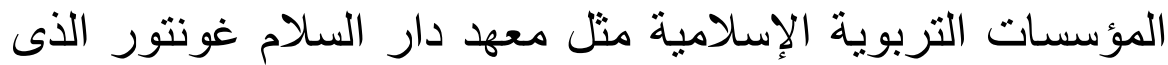
ترك الطريقة القديمة طريقة القواعد والترجمة وطبة الإنة الطريقة

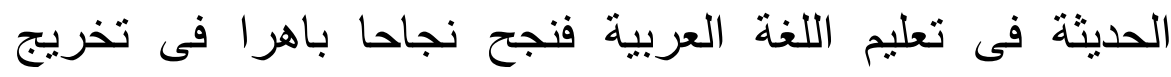
الخريجين المجيدين باللغة العربية كتابة و محادثة. - ـ رائد تعليم اللغة العربية مانهة ـ كلية الآداب ـ الطريقة المباشرة.
\end{abstract}




\section{ألم مقمة}

اللغة العربية هى اللغة الوحيدة فى العالم التى لم يطر أعليها تغيبرات

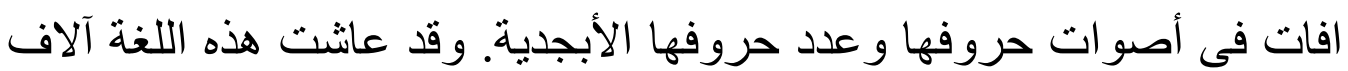
السنين فى موطنها الأول فى الحجاز وانتشرت وتكاثرت فئر في بلاد كثيرة

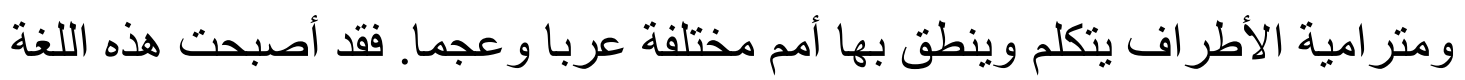
لغة باقية وشبه مقدسة حينما نزل القرآن الكريم بها إلى النبي العربي القرشيى سيدانيا

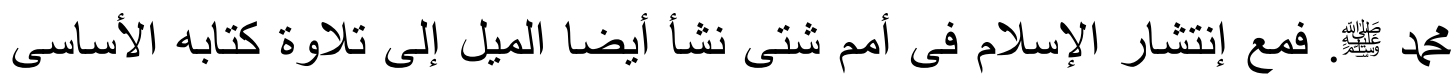

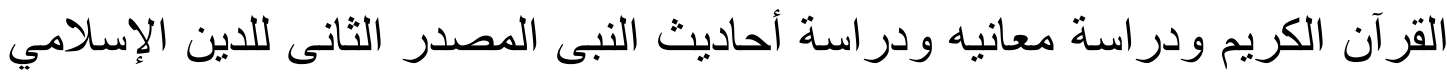

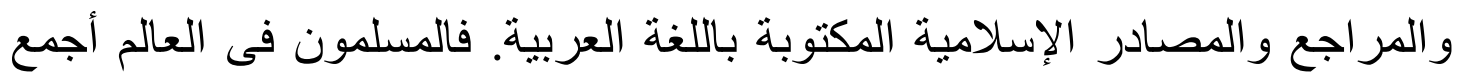

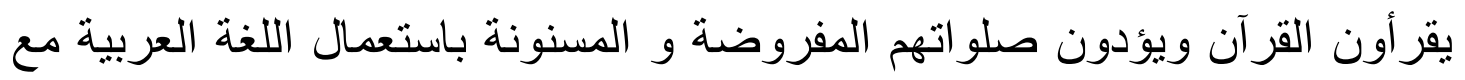
أن كثير ا منهم لا يتحدثون بها في حياتهم ومعاملاتهم اليومية.

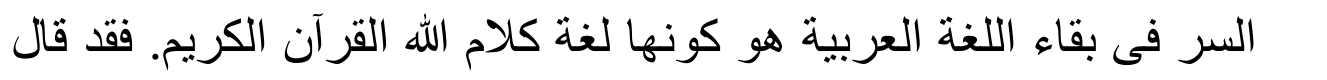

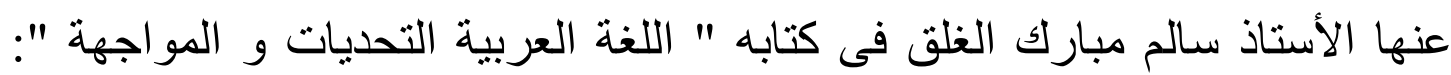
(9-8 :

العربية لغة القرآن الكريم، وهو مهيمن على ما سواه من الكتب الأخرى : لكى

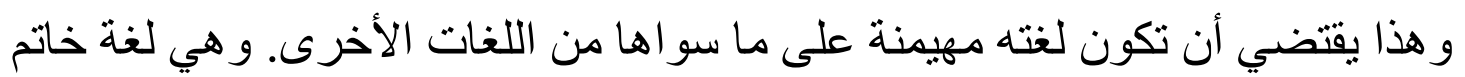

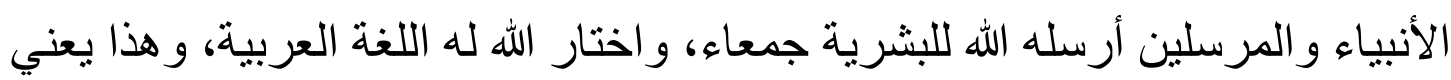

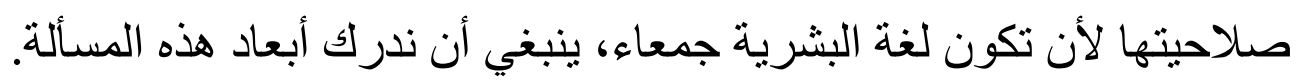

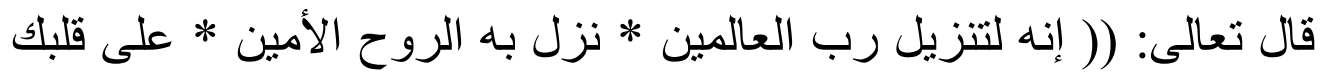

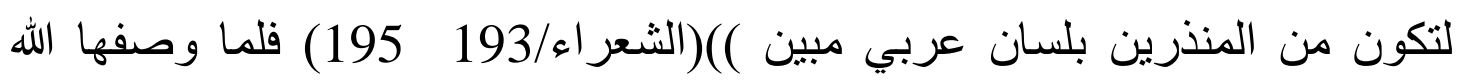

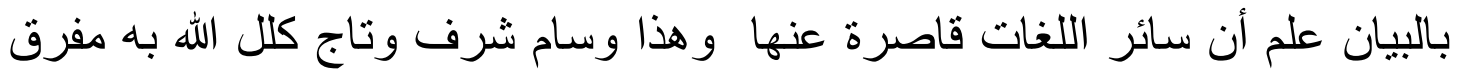

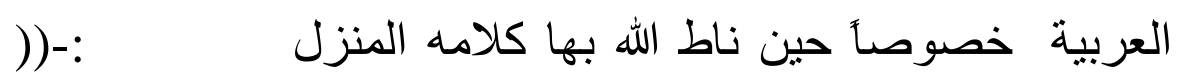

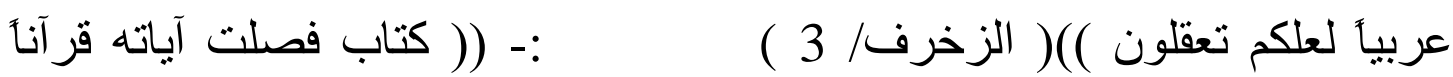

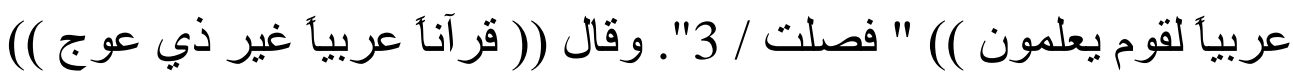

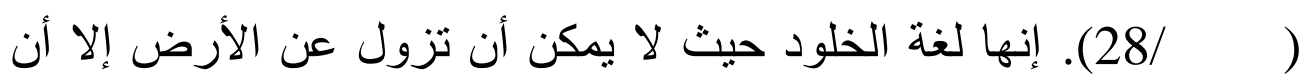

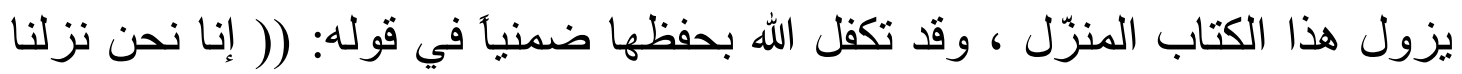

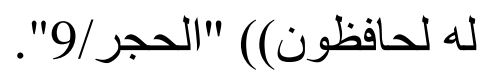


ومن الطريف ما ذكره محمد الخضر حسين: (( كتب "جون فرن" قصة خيالية

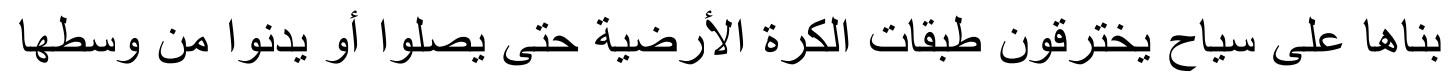

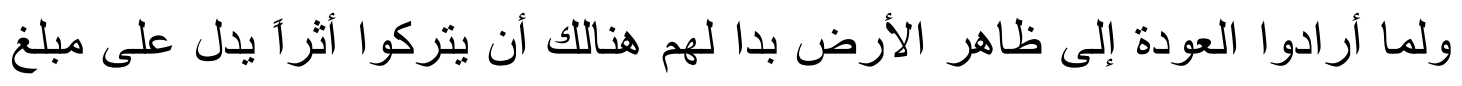

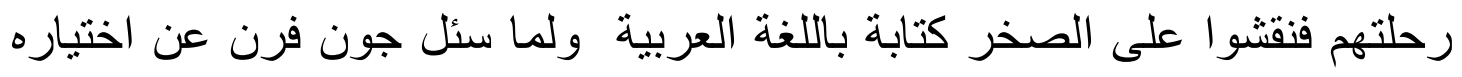

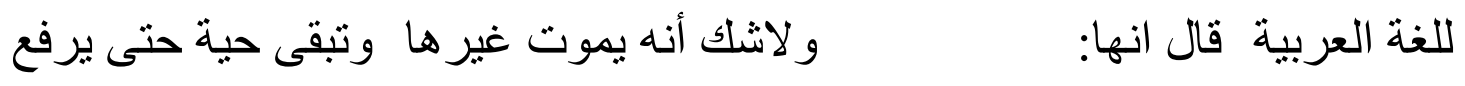

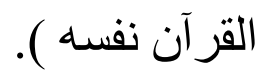

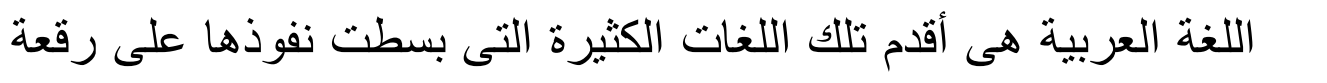

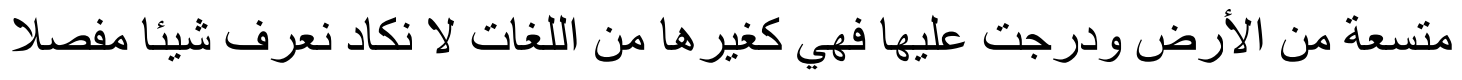

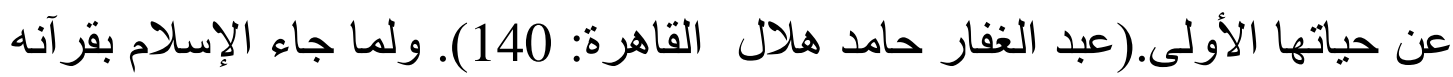

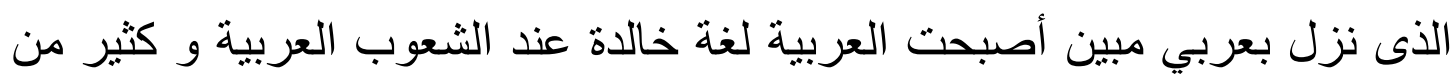

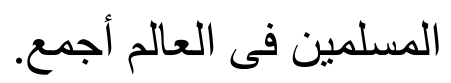

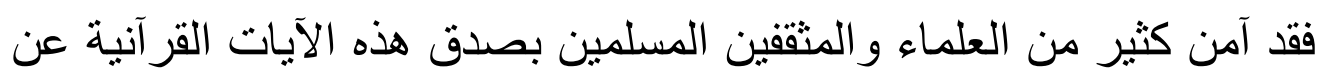

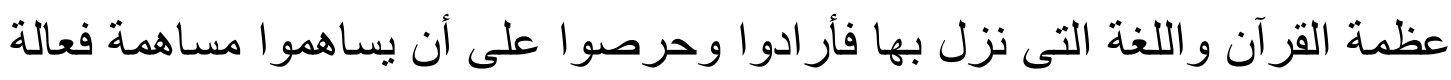
لمحافظة هذه اللغة العربية ونشرها و تربلة تعليمها بين أبناء وطنهم.

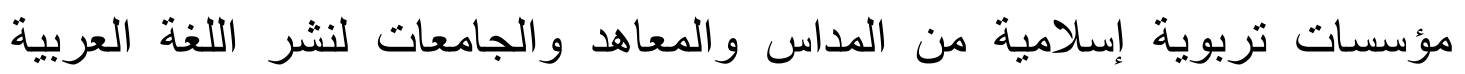

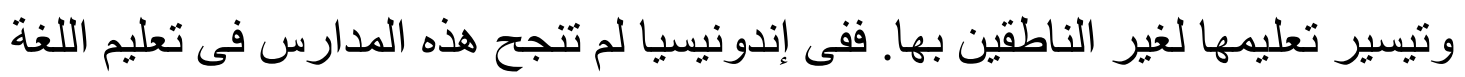

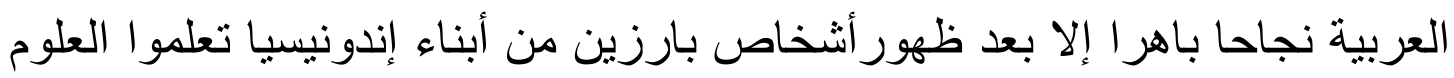

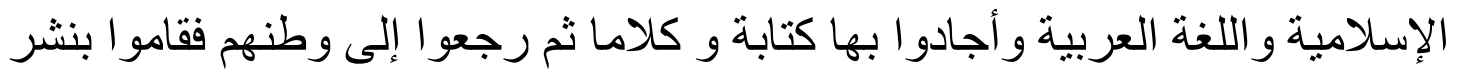

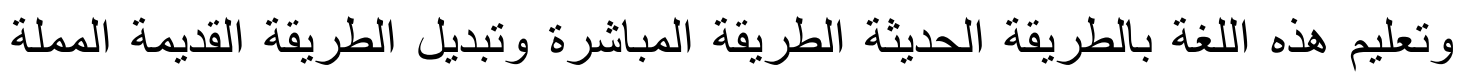

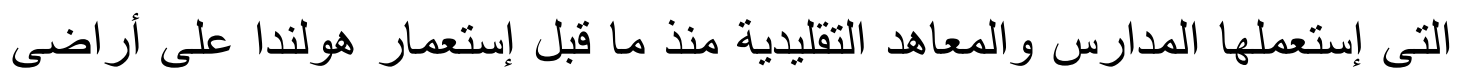

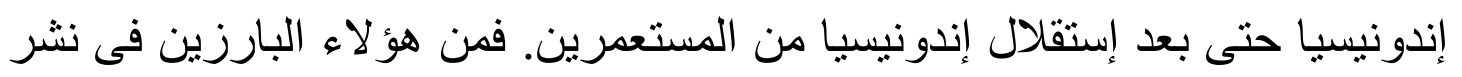

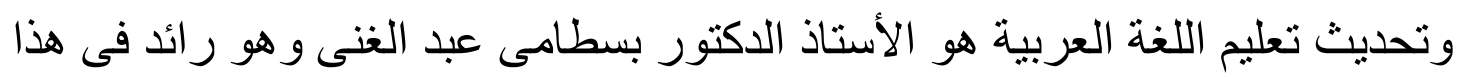

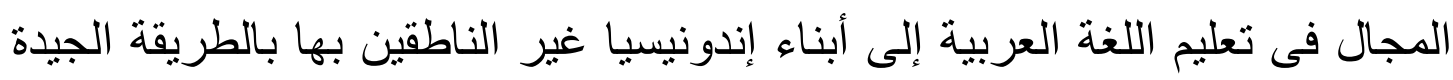
الحديثة التى أخرجت المجيدين باللغة العربية كتابة وسماعا وقر اءة و كلاما.

ب. بسطامى عبد الغنى حياته وتعاليمه 
بوكيت تتجى سومطرة الغربية

إندونيسيا في24 ديسمبر 1912 (9-8: Setyadi Sulaiman).

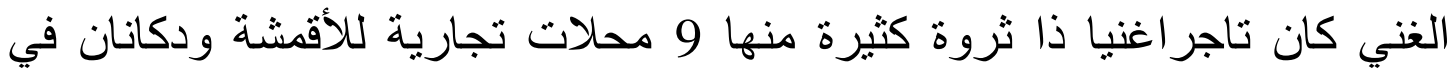

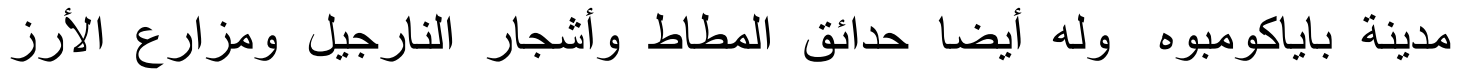

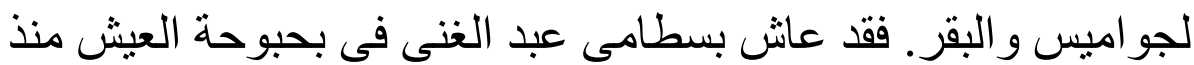
صغره. وكان المجتمع الذي يعيش فيه مجتمعا دينيا تحت ظل التعاليم الإسلامية

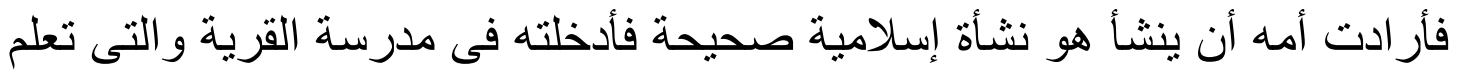

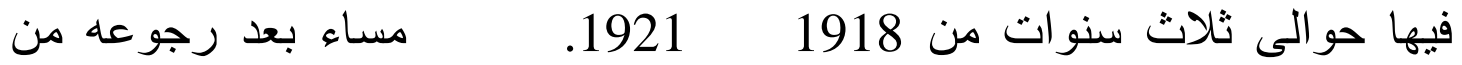
المدرسة ذهب إلى المدرسة الدينية قرب بيته لتعلم مبادئ الدروس الإسلامية وفى لئى

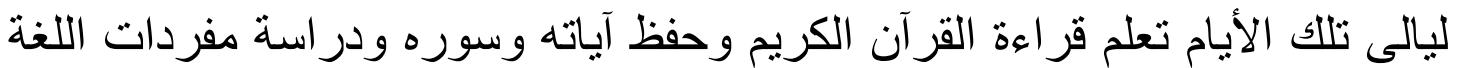
العربية تحت رعاية وإرشاد وتعليم عدد من الأساتذة فى المسجد القريب من مسكنها.

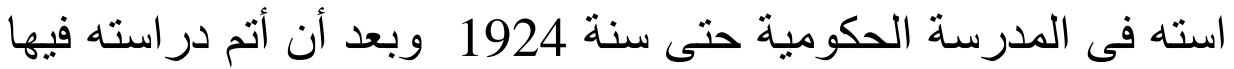

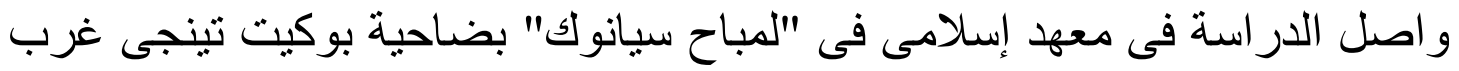

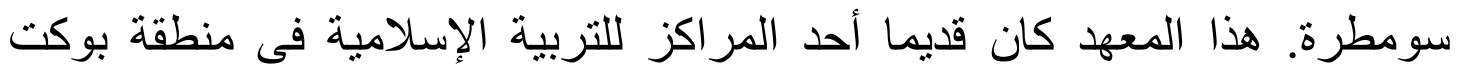

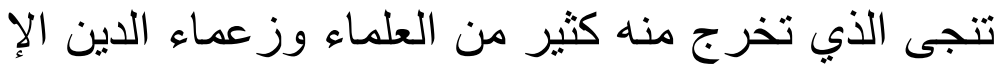

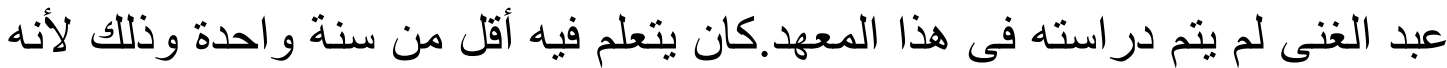
كان يتمنى أن يتعلم اللغة العربية و العلوم الإسلامية فى مدينة ميلاد الإسلام مكة فئه فئه المكرمة. فقد تحققت أمنيته عندما أر اد أبوه لأداء فريضة الحفة الحج في سنة 1926.

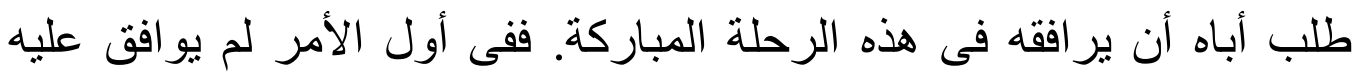

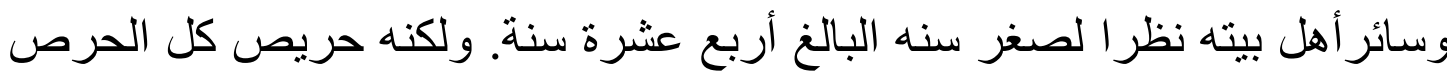
لمصاحبة أبيه لأداء فريضة الحج إلى بيت الله بمكة المكرمة حتى سمحو اله أن يحت النه

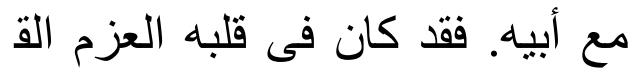
الدول العربية ولم يعبر هذا العزم إلى عشيرته الأقربين إلا مصاحبة أبيه لحجة بيت الله. فقد كان السفر للحج فى ذللك الوقت ذامشقة عظيمة و متعبة واستغرق أنثهرا بركوب السفينة الثراعية. ففى أواسط سنة 1926 غادرت السفينة التى ركب فيها فئه

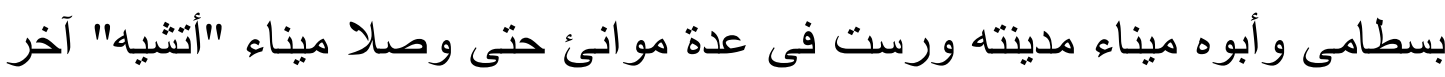

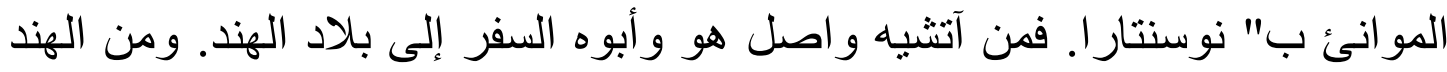


طلبا الباخرة التى ستحمهم إلى حضرموت اليمن أوجدة. فقد وجدا أخيرا الباخرة التي

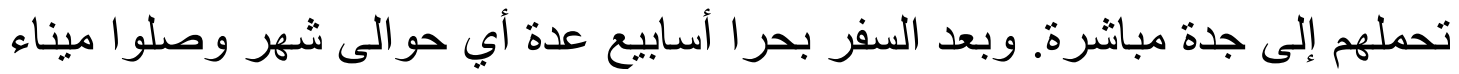

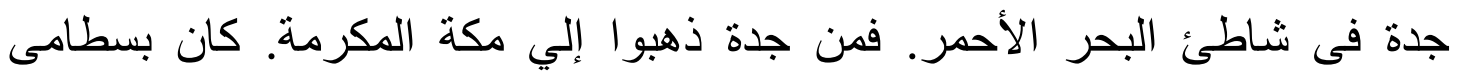

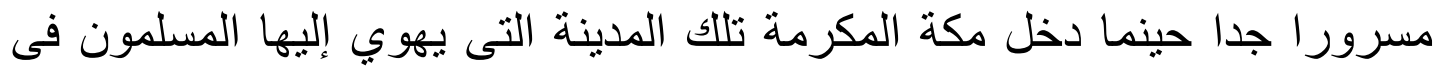

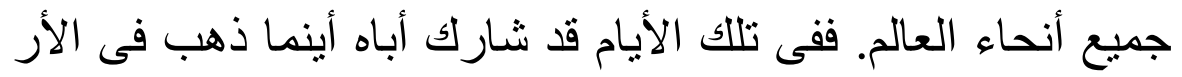

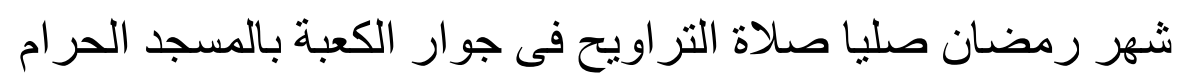

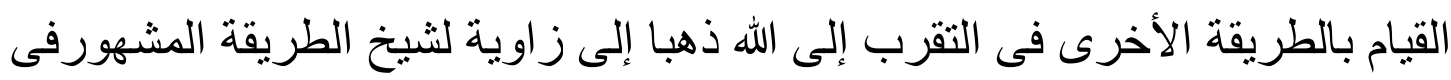

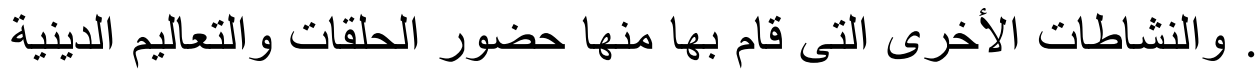

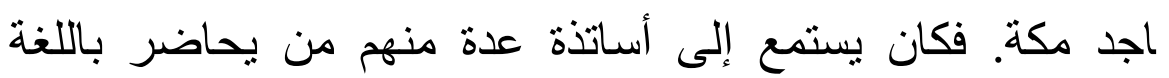

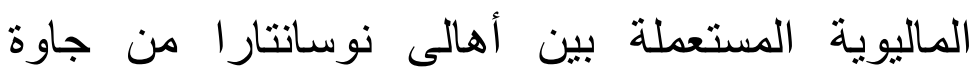

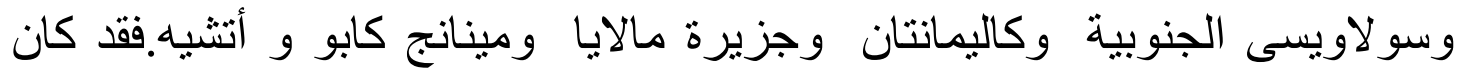

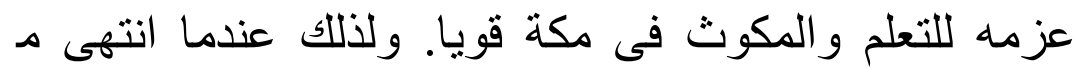

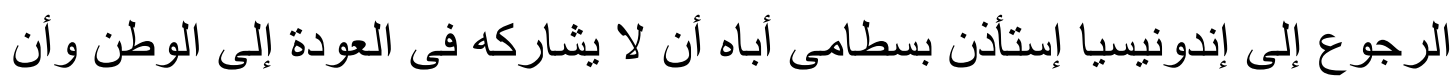

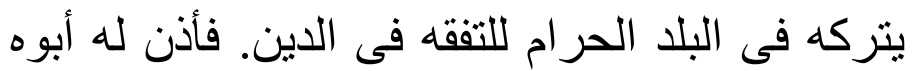

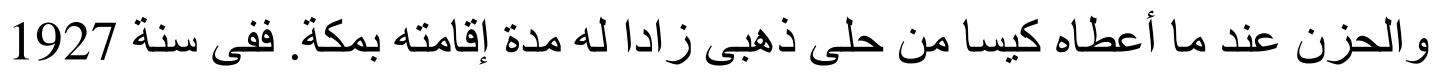

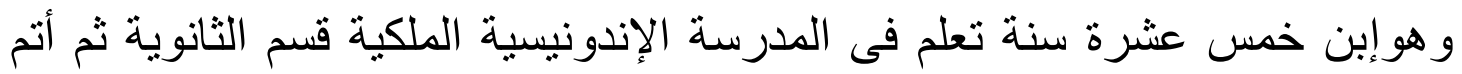

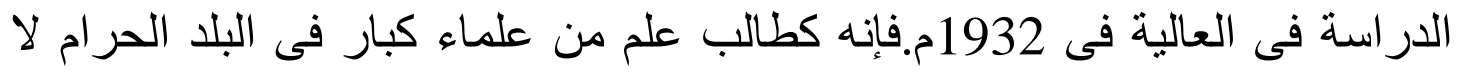

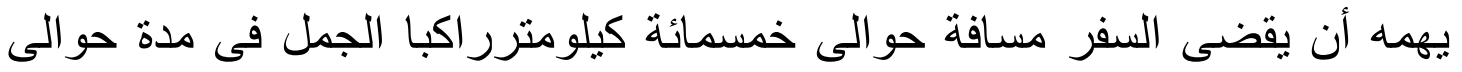

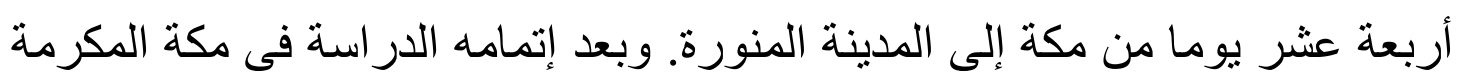

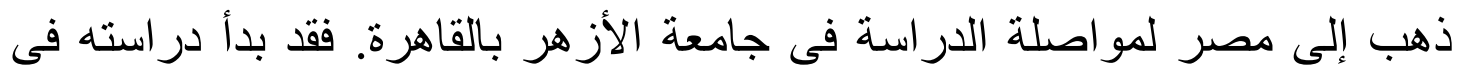

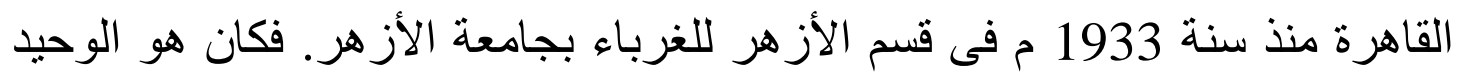

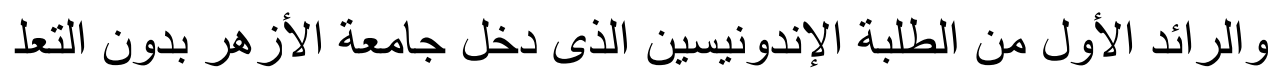

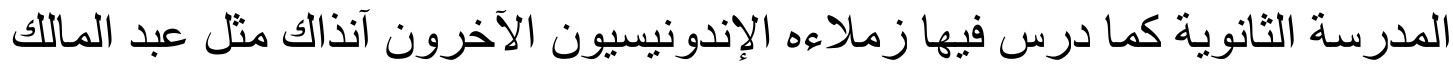

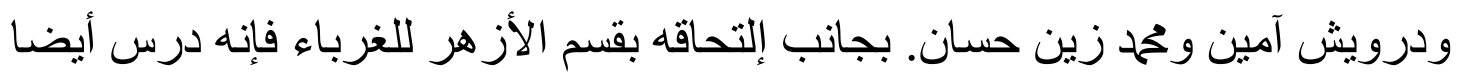

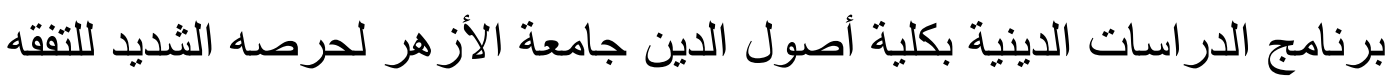


ثم و اصل الدراسة فى مدرسة دار العلوم المشهورة حينذالك كجامعة مصرية

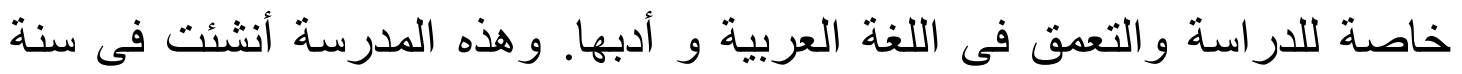

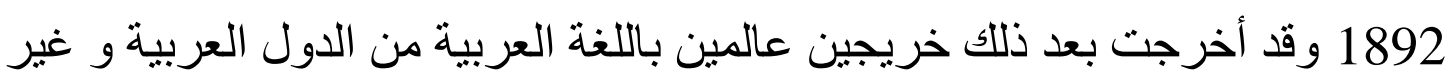

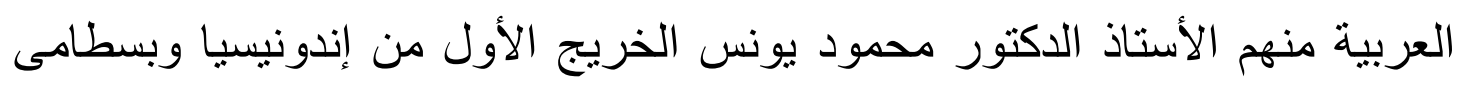

$$
\text { ففى هذه المدرسة عرف بسطامى عبد الغنى إسم محمود يونس }
$$

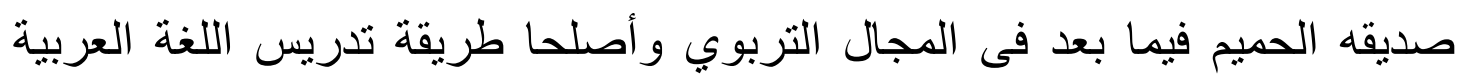
باندونيسيا. و الدكتور محمود يونس هو الذي قال قولته الثهيرة فى كتابه " التربية و

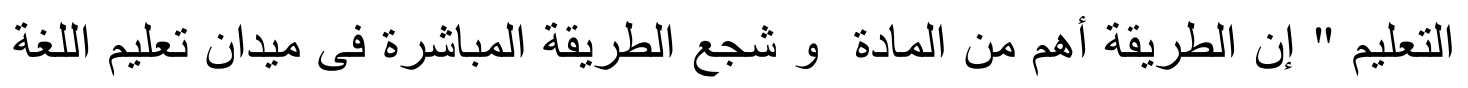
العربية للناطقين بغير ها فى إندونيسيا.

بسطامى عبد الغنى على إجازة التدريس لدار العلوم وهذه الثهادة أعطتها له وز 1357 1938

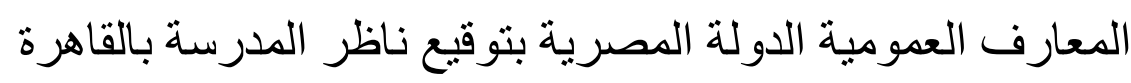

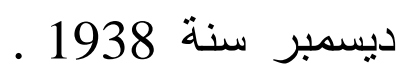
بالسيدة مريم بنت الشيخ إبر اهيم موسى بار ابيك مؤسس مدرسة سومطرة طو الب.

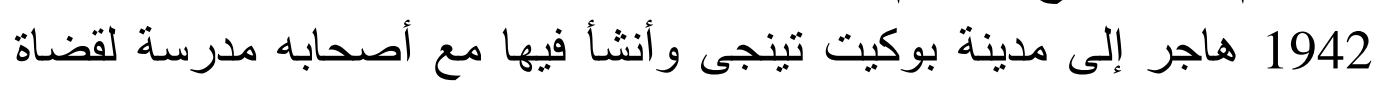

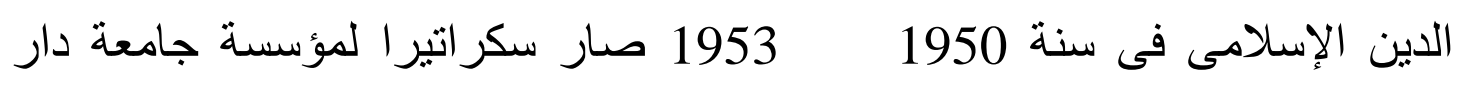
الحكمة ببوكيت تينجى. وفى عام 1954 عينته الحكومة الإندونيسية موظفا حكوميا

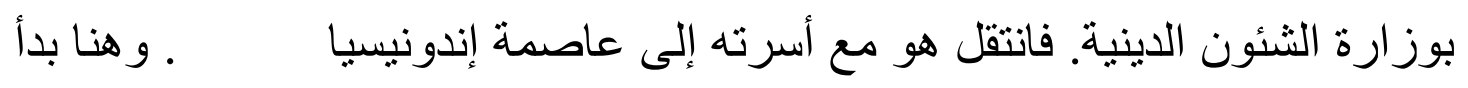

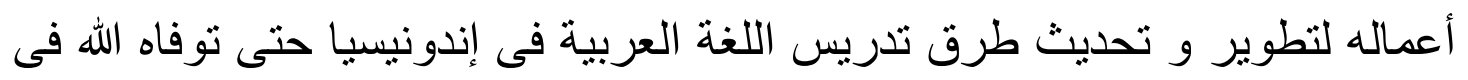
21 أبريل 2001.

\section{بأعماله ومؤلفاته}

1938 رجع بسطامى إلى وطنه إندونيسيا و وبدأ أعماله مدرسا

فى كلية المعلمين الإسلامية ببادنج أو Normal Islam School

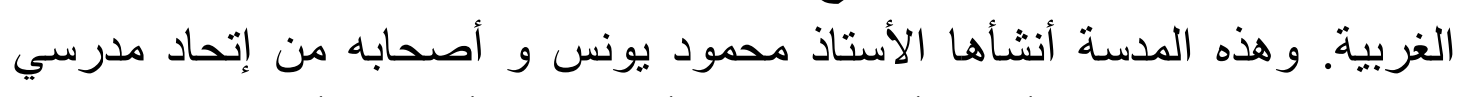
الدين الإسلامى الذى تر أسه الأستاذ عبد الله أحمد فى الأول من أبريل ألاذ 1931. 
يلبث طويلا أن عين بسطامى نائبالمدير هذه المدرسة. وقد أستعمل فى هذه المدرسة

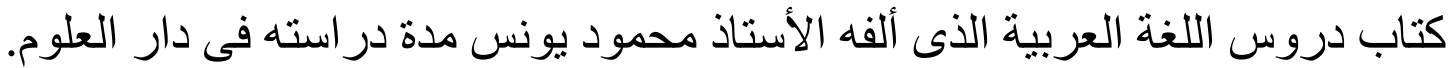

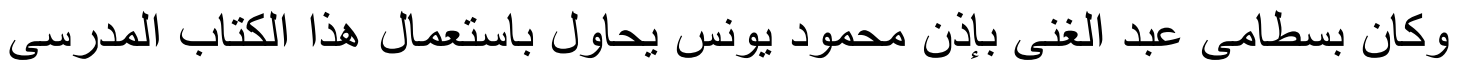

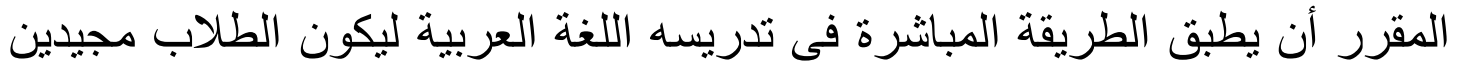

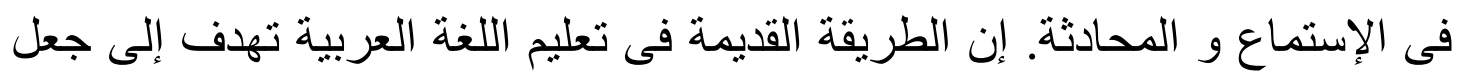
الطلاب ماهرين فى الترجمة وفاهمين للنصوص العربية. ولكن بسطامى عبد الغنى

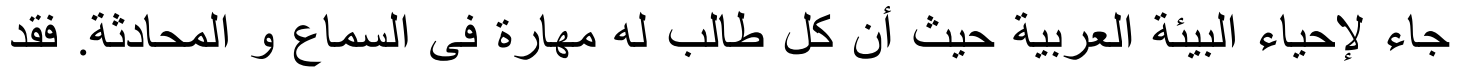

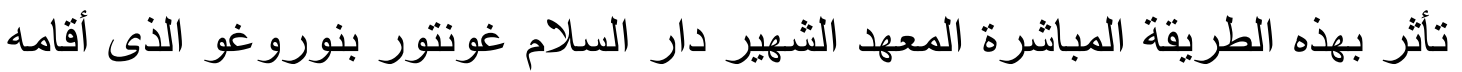
الثيخ الإمام زركثى أحد خريجى كلية المعلمين الإسلامية.

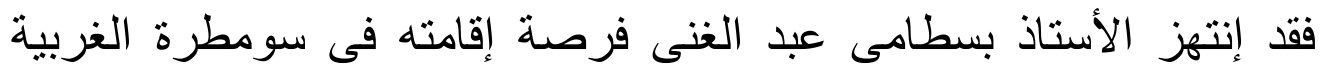

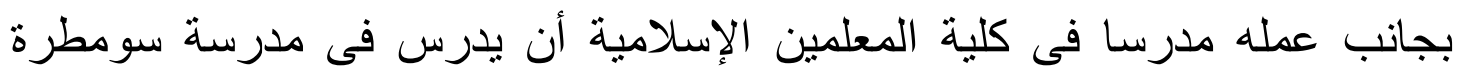

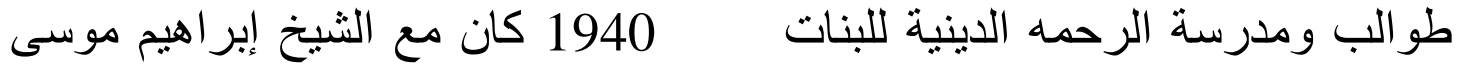

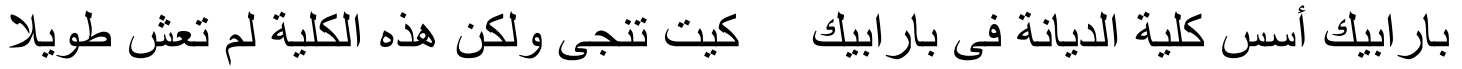

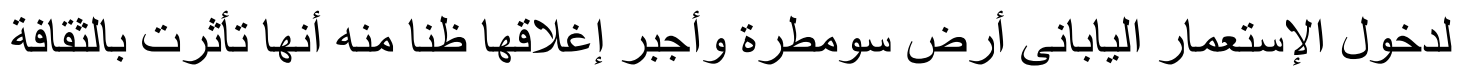
الغربية الهولندية.

1954 هاجر بسطامى و أسرته إلى جاكرتا لأنه صـار موظفا حكو ميا

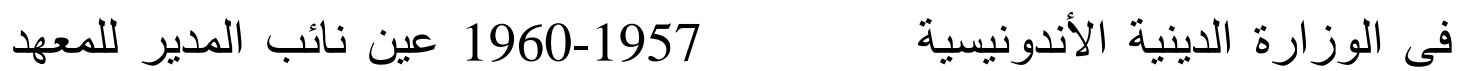

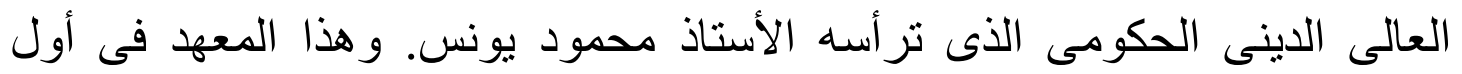

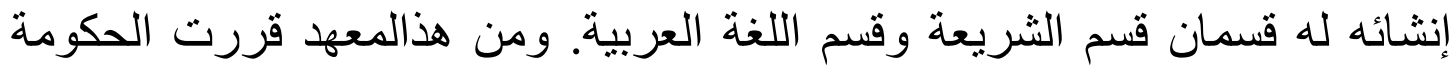

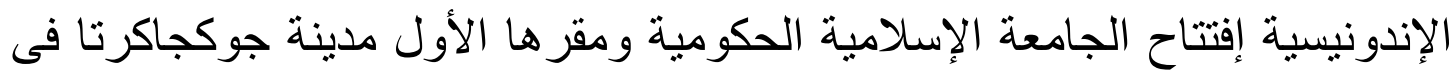

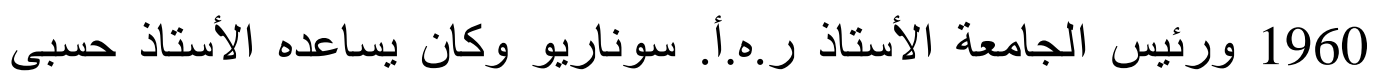

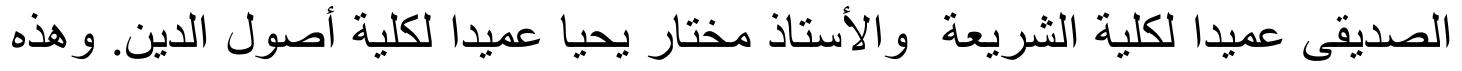
الجامعة لها كليتان بجاكرتا كلية التربية و عميدها الأستاذ محمود يونس وكئس وكلية

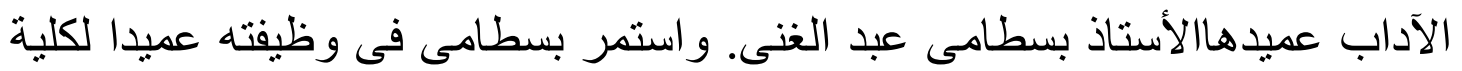
19721960 
إن الأستاذ بسطامى عبد الغنى قد نرك آثار اكثيرة منها الكتب الدراسية

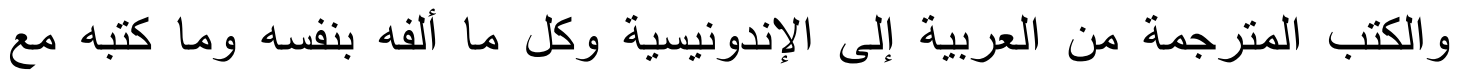
الآخرين أو تحت إثر افه حو الى تسعين كتابا فى مختلف المجالات العلمية من اللغة التها

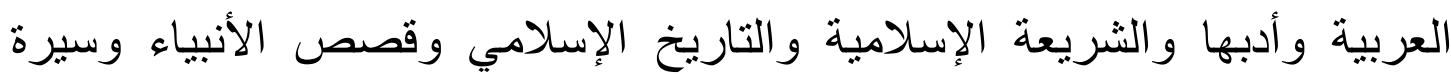

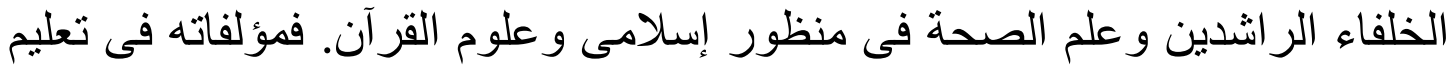

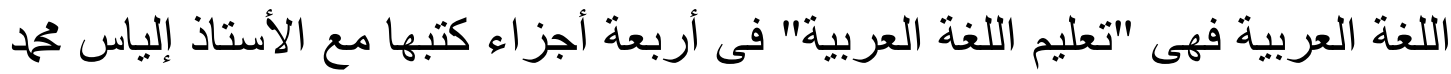
1950 أصدر ها مطبعة دارا

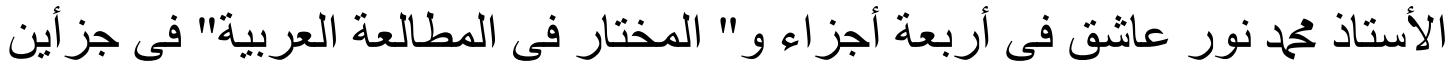

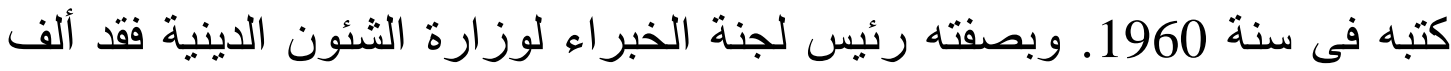

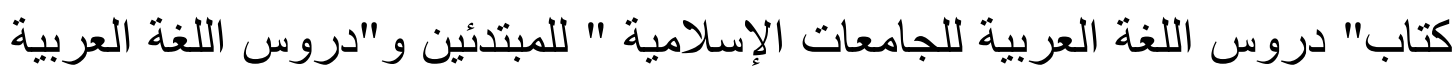

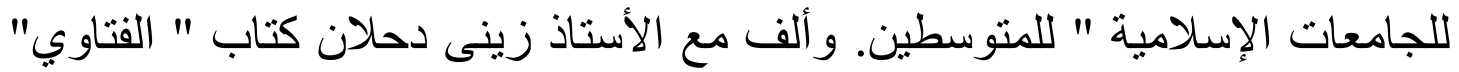

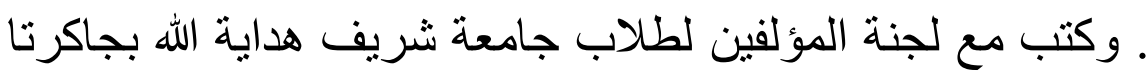

$$
\text { كتاب " العربية بالنماذج " فى سبعة مجلدات }
$$

\section{ج. طرق بسطامى عبد الغنى فى تعليم اللغة العربية}

هناك طرق عدة لتعليم اللغة منها طريقة القو اعد و طريقة الترجمة و الطريقة

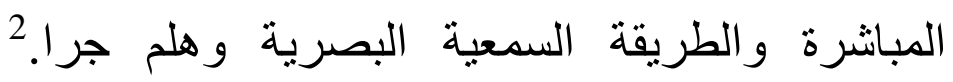

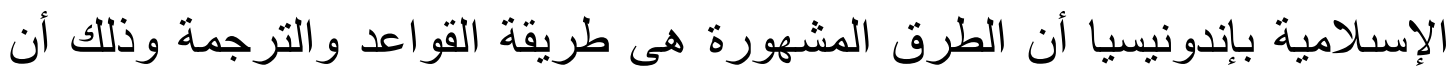
كثثرا من مدرسي اللغة العربية الذين لا يجيدون المحادثة والكتابة باللغنة الكئة العربية

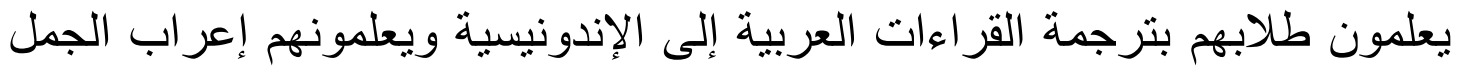
و الكلمات العربية ولوكانو ال الفهمونها جيدا. ففى نظر بسطامى عبد الغنى وزملاءه الغيه

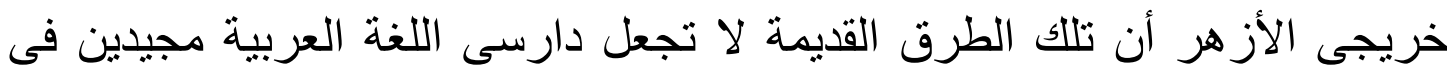

$$
1 \text { - حمحد نور عاشق و بسطامى عبد الغنى رفيقى فى المطالعة العربية والمحفوظات }
$$

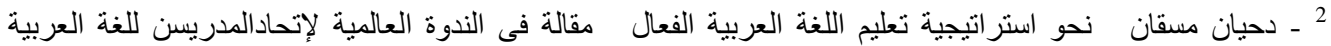
2005

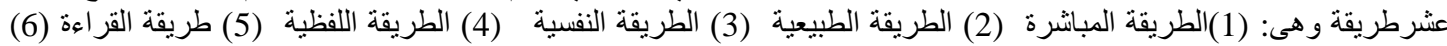

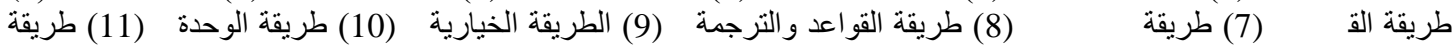

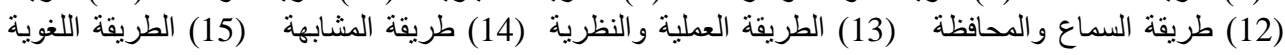


المهارات الأربع المحادثة والإستماع والقراءة والكتابة فى اللغة العربية. فكان

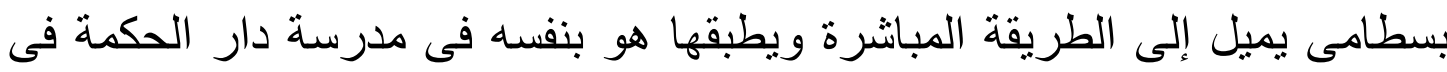

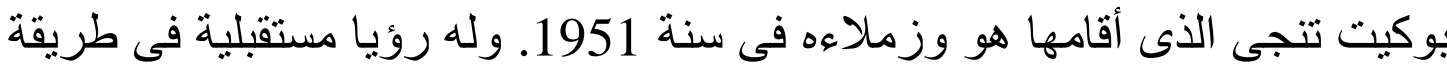

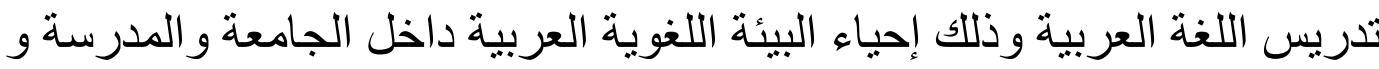

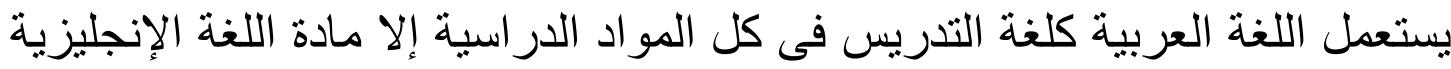

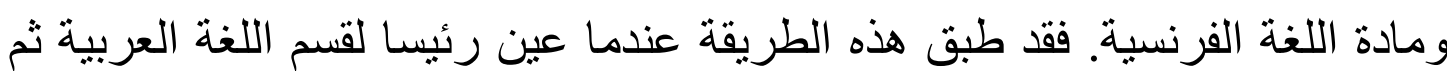

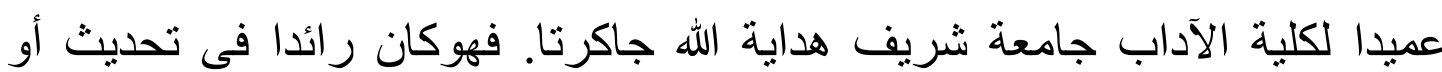

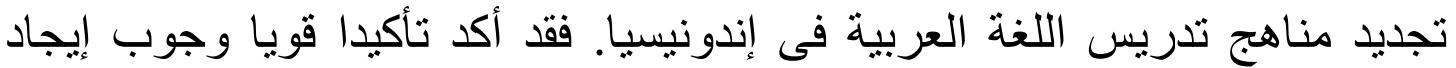

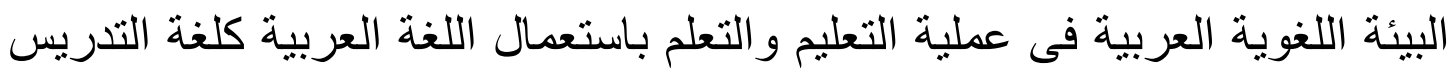

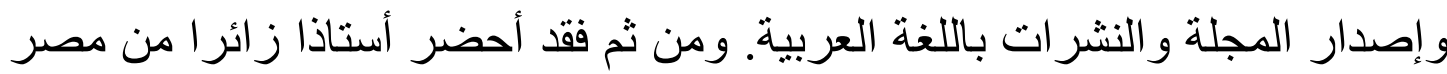

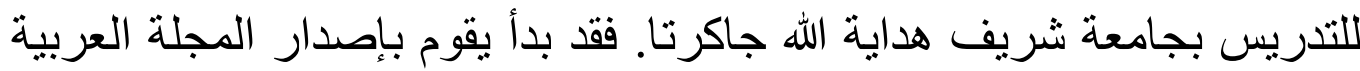

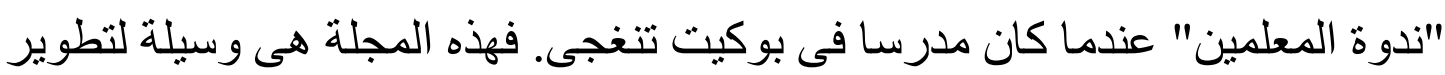

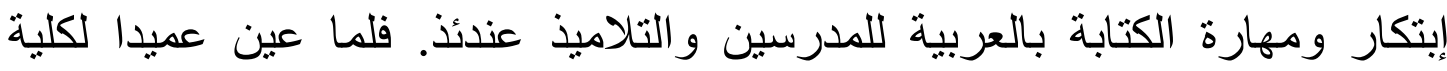

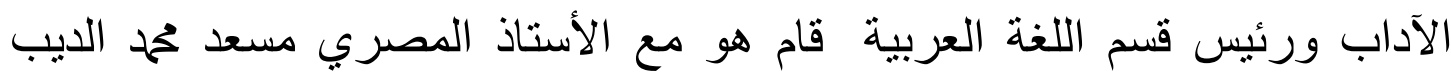

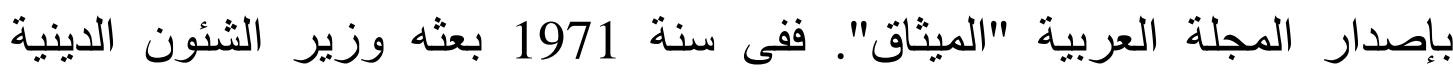

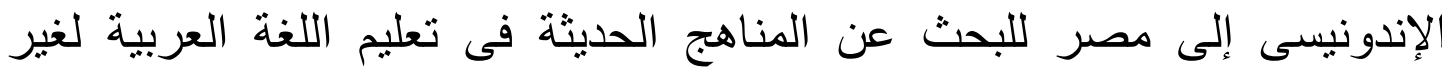

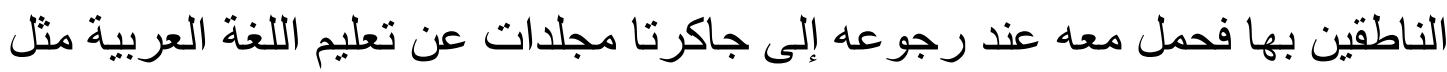

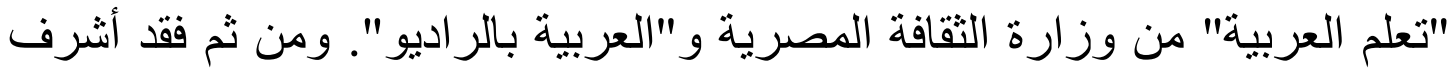

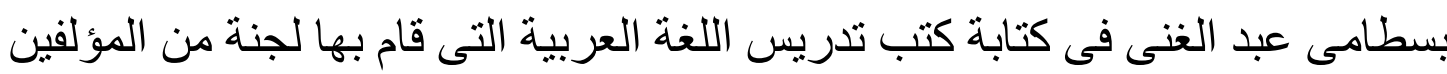

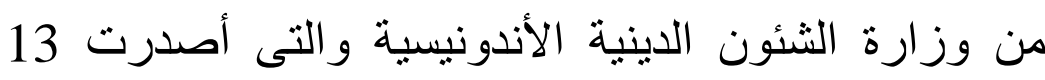

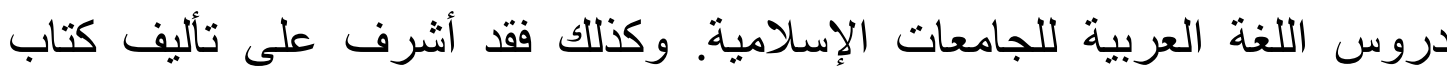
العربية بالنماذج فى سبعة أجز اء. فقد إستخدمت هذه الكتب نظئ نظرية الوحدة و الطريقة

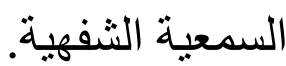

ففى الكتاب الذى ألفه مع الأستاذ إلياس محمح على "تعليم اللغة العربية"

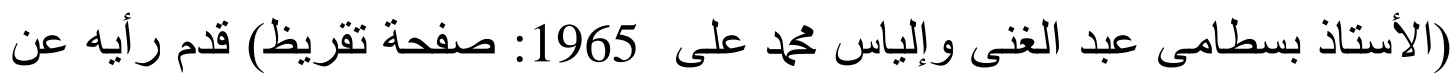
تدريس هذا الكتاب وإرشاداته للمدرسين فقال: 
يجب على المدرس أن بهنم بما يأتى ويعتنى به إعتناء تاما:

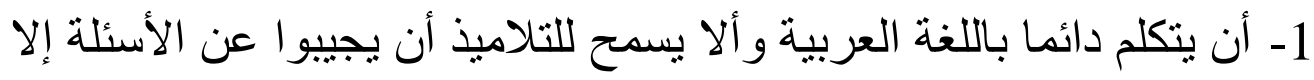
باللغة العربية حتى يكون جو الحصة جو ا عربيا خالصا. 2- أن يعتنى كل الإعتناء بأن ينطق التلاميذ الحروف من اعن مخارجها الصحيحة.

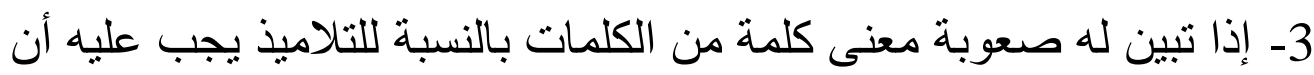

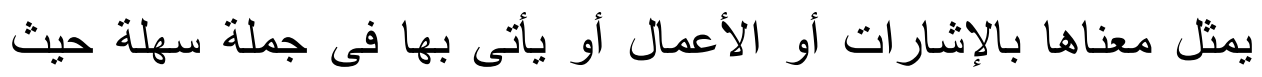

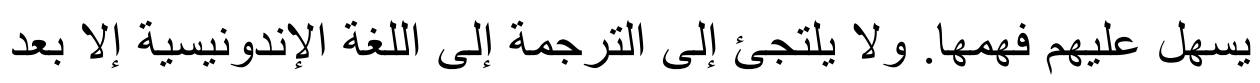

$$
\text { 4- أن لاينتقل من عجز هم. }
$$

إجادة تامة وتمرين التلاميذ عليه كثير ا و هكذا فى بقية الدروس.

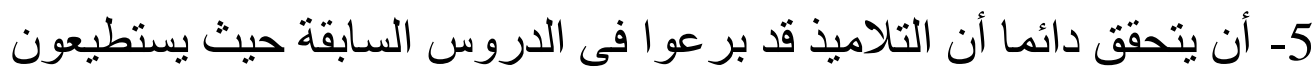

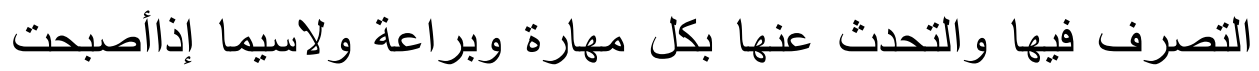

$$
\text { ست كثيرة. }
$$

6- إذا شعر بأن درسا من الدروس كان طويلا أو صعبا لا بأس عليه أن يتم

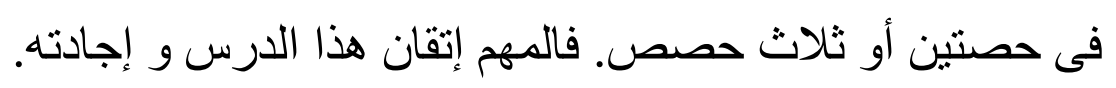

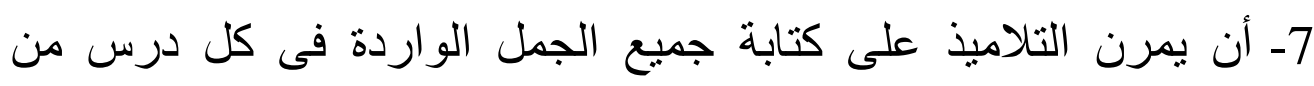

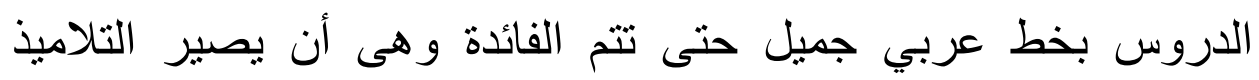

$$
\text { ماهرين فى اللغة العربية تحدثا وكتابة. }
$$

وقبل الإختتام نود أن نقتطف نموذجا من كتاب نعليم اللغة العربية الذى ألفه

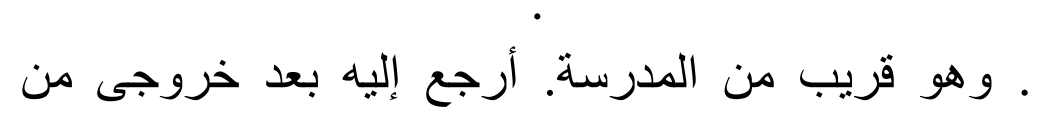

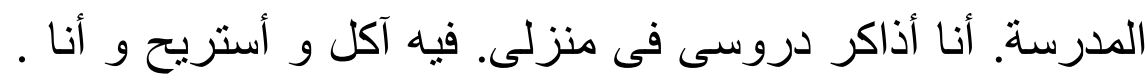

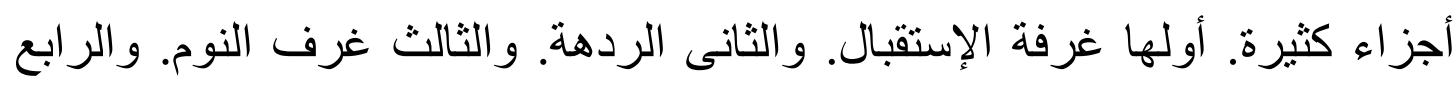


فأنا أستقبل الضيوف فى غرفة الإستقبال.

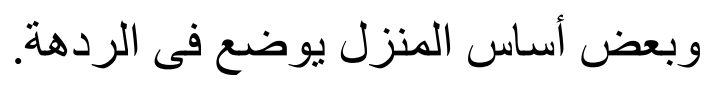

أين تذهب بعد الخروج من المدرسة أذهب إلى المنزل.

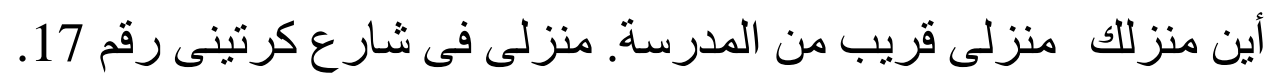
أين تذاكر

أين تأكل كم مرة تأكل فى اليوم؟ آكل فى اليوم ثناث مرات. منى تذهب إلى النوم؟ أذهب إلى النوم في في النى الساعة العاثترة. أين تنام

متى تستيقظ أستيقظ فى الساعة الخامسة صباحا. أين تقضى حاجناك و أين تستحم؟ أستحم فى القصى الحمام.

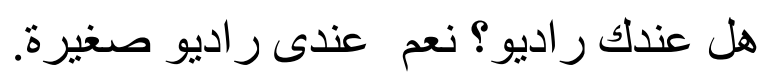

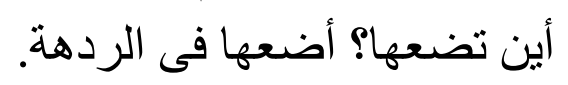
لماذا تضعها فى الردهة؟ لكى يمكن سماعها من جميع أنحاء البيت.

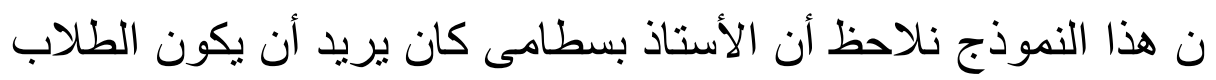

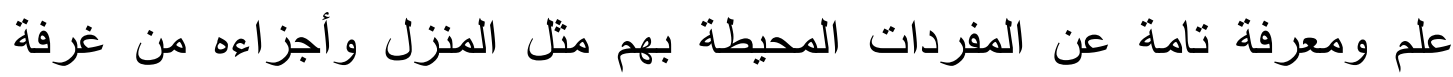
الردهة

وكذلك لم يستعمل جميع الضمائر فى اللغة العربية إلا لها علاقة بالنص وهى ضمير مثل جملة " أرجع إليه 
وضمير "أنت " فى مثل جملة " أين تنام متى تستيقظ أين تستحم

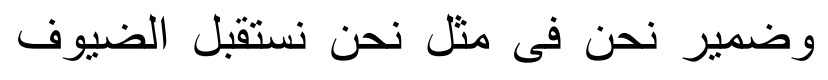

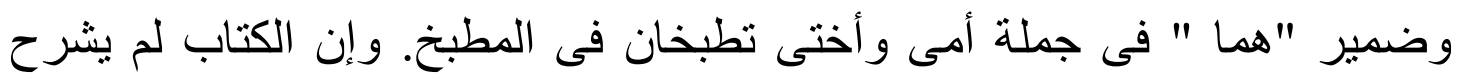

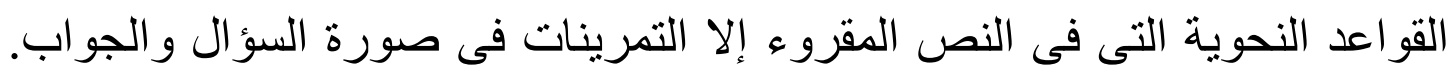

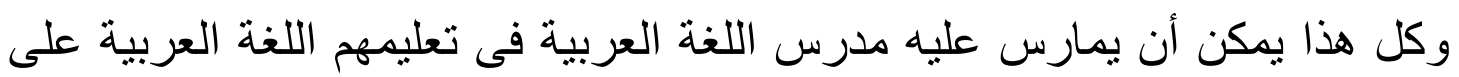

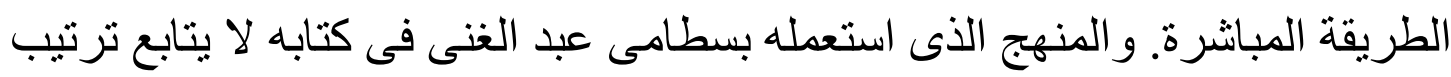
النحو و الصرف بل يستعمل ما يسمى الآن بالمدخل الإتصالى أو المدخل الإنسانى

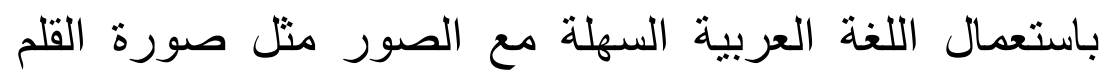
وصور أجزائه. وهو يريد أن يطبق مبدأ " يسروا و لا تعسروا".

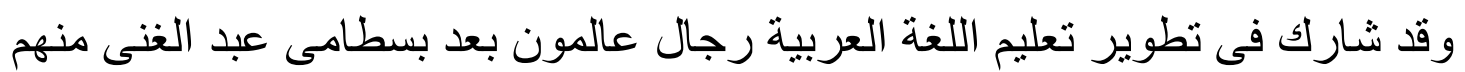

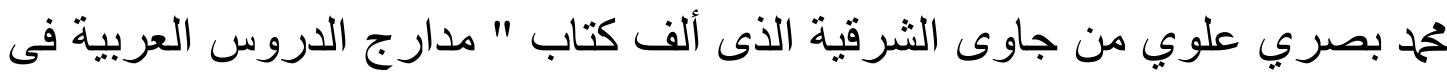

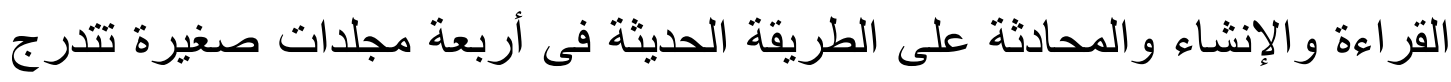

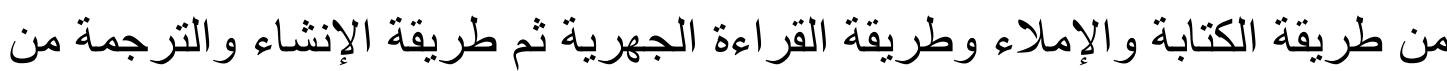
العربية إلى الأندونيسية و عكسها من الأندونيسية إلى العربية ثم طريقة الإحادثة

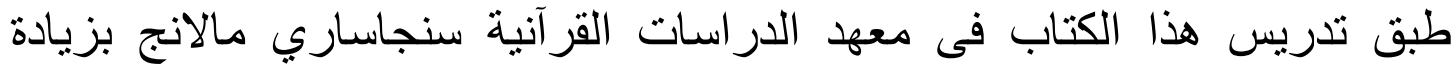
تغريد طريقة الألعاب مثل الأناشيد

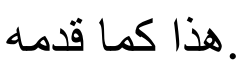
مشاهد |الأستاذالدكتور حسن يوسف فى بحثه ( الإستو اء مجلة فصلية علمية محكمة 2 | 2014: 75 - 75

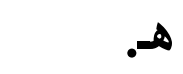
لاشك أن الرجال مثل بسطامى عبد الغنى ومحمود يو نس وغيرهم من فئن العلماء المجيدين باللغة العربية الفصحى لهم فضل عظيم وتأثير كثثير فى تقدم وتطور

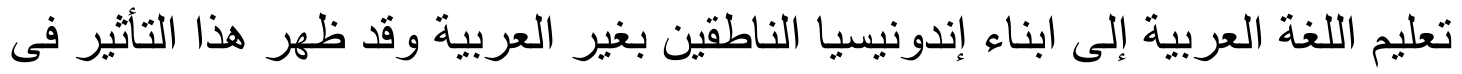
تطبيق معظم المدارس والمعاهد والجامعات الإسلامية وغير الإسلامية الطريقة

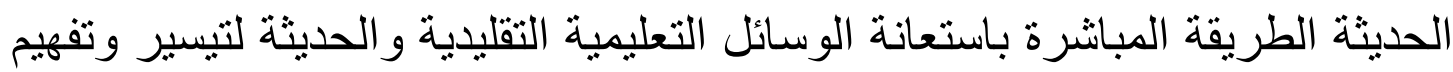

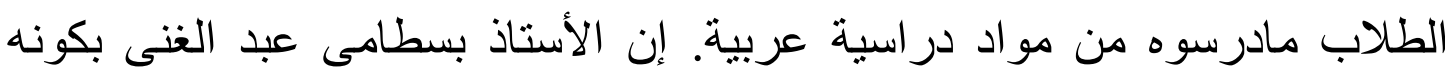

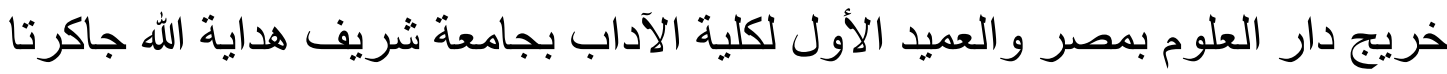




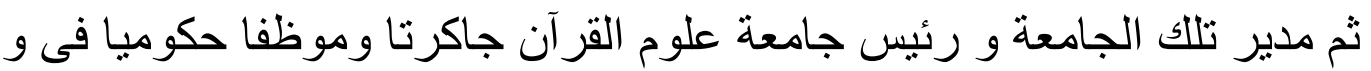

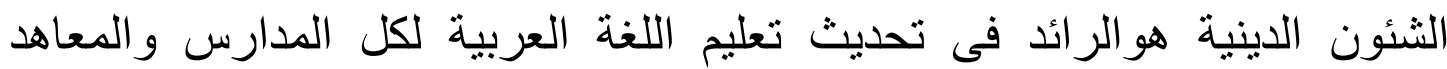

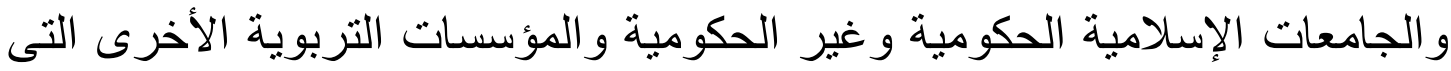

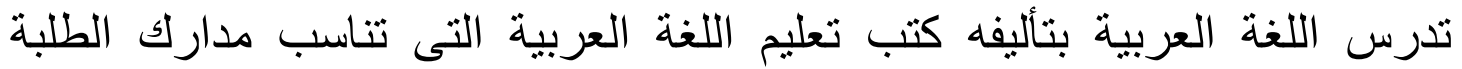
الإندونيسين من مناظر وحالات إجتماعية.وهو الذى شجع الطريقة المباشرة

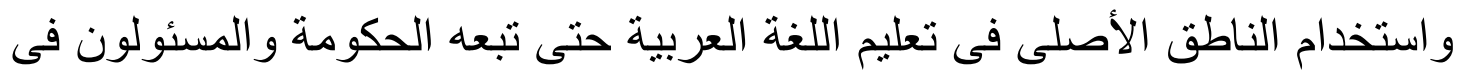

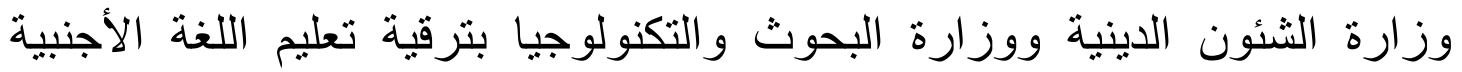
العربية والأنجليزية تناسب عصر العولمة عصر الأنترنت باستعمال الطريقة الحديثة

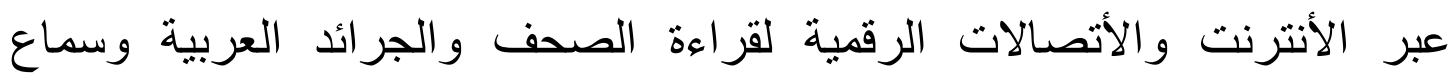

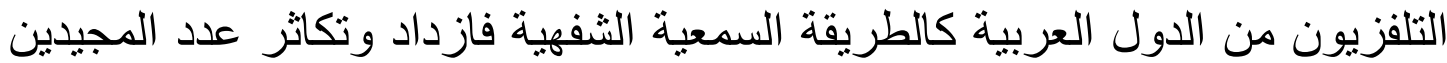

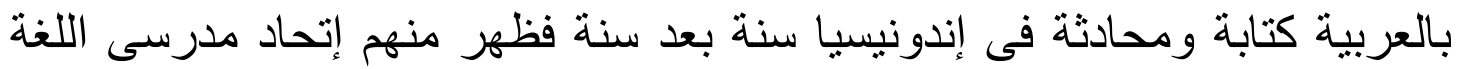

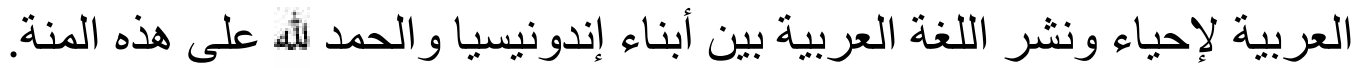

\section{المراجع}

Setyadi Sulaiman, Sang Begawan Bahasa Arab, Adabia Press. Fakultas Adab dan Humaniora. UIN Syarif Hidayatullah Jakarta. 2013.

التأديب، دحية مسقان نحو استر اتيجية تعليم اللغة العربية الفعال Jurnal Kependidikan Islam, Vol. 3, No. 2, Fak. Tarbiyah ISID Darussalam, Gontor, 1428.

دحية مسقان اللغة العربية ودور ها الفعال فى صباغة الحركة العلمية Pondok ISID Jurnal Ilmu Pengetahuan dan Kebudayaan Islam Tsaqafah Indonesia Gontor Modern Darussalam 
محي الدين الألوائى الطريقة المثلى لتعليم اللغة العربية لغير الناطقين بها

بحث فى مجلة الجامعة الإسلامية بالمدينة المنورة $1401212 \quad 460$ اللغة العربية معناها ومبناها الهيئة المصرية العامة للكتاب

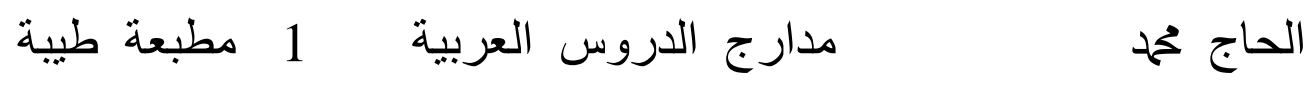

, أبريل

1983

\section{إندونيسيا}

مجلة تعليم اللغة العربية مو لانامالك إبر اهيم

$$
\text { غة العربية }
$$

Arsyad, Azhar. Dasar-Dasar Penguasaan Bahasa Arab. Pustaka Pelajar, Yogyakarta, 2002.

Arsyad, Azhar. Menguasai Kata Kerja Populer Preposisi Bahasa Arab Pustaka Pelajar Yogyakarta 2001.

محمد نور عانثق رفيقى فى المطالعة العربية والمحفوظات ه وزاد عليه

$$
.1976
$$

$$
\text { اللغة العربية التحديات و المواجهة }
$$

Umam, Chatibul. Aspek-aspek Fundamental dalam Mempelajari Bahasa A rab, PT. Almaarif, Bandung, 1980.

عبد الغفار حامد هلال العربية خصائصهاو سماتها مكتبة وهبة القاهرة

Jakarta Al-Hidayah 2 محمود يونس دروس اللغة العربية 
Hidayatullah, M. Syarif \& Abdullah, Pengantar Linguistik Bahasa Arab Lembaga Penelitian UIN Syarif Hidayatullah Jakarta 2010.

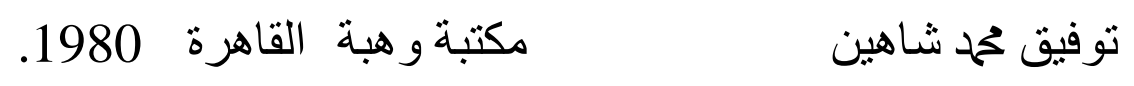

Hubeis, U. \& A. Yazid, فقه اللغة العربية Jilid II, Pembina, Surabaya, 1957.

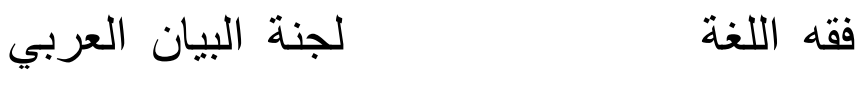

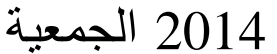

مجلة علمية فصلية محكمة

المصرية للدراسات السردية كلية الآداب والعلوم الإنسانية جامعة قناة السويس

بسطامى عبد الغنى و إلياس حمد على تعليم اللغة العربية

2014

الإستواء مجلة فصلية محكمة

و الدر اسات الإندونيسية جاءعة قناة السويس 